\title{
Fish biomarker responses to perturbation by drought in streams
}

Correspondence:

Luciana de Souza Ondei luondei@yahoo.com.br
Submitted December 3, 2019

Accepted March 31, 2020

by Bernardo Baldisserotto

Epub Jun 29, 2020

\section{${ }^{\oplus}$ Luciana de Souza Ondei ${ }^{1,2},{ }^{\oplus}$ Fabrício Barreto Teresa ${ }^{1},{ }^{\oplus}$ Danielly Pereira Garcia ${ }^{2},{ }^{\oplus}$ Andréia Arantes Felício ${ }^{2},{ }^{\oplus}$ Danilo Grünig Humberto da Silva ${ }^{2}$ and ${ }^{\oplus}$ Eduardo Alves de Almeida ${ }^{2,3}$}

Drought can be viewd as a perturbation in running waters and fish are often trapped in isolated pools, where deterioration of water quality may be stressful. We investigated how this extreme condition influences response of oxidative stress biomarkers. The response of the characid Astyanax elachylepis was assessed during the dry and rainy seasons in intermittent and perennial (control) sites in streams from Brazilian savannah (Cerrado). We predicted that the biomarkers would be enhanced in the dry season in intermittent streams only due the environmentally harsh conditions in the few isolated pools that remain filled with water. As predicted, fish from the intermittent stream in the dry season presented higher gill MDA values, indicating greater stress. In the liver, MDA values were higher in the dry season for both intermittent and perennial streams, suggesting a generalized seasonal response. As expected, some antioxidant response enzymes changed in the intermittent sites during the dry season. Therefore, oxidative stress biomarkers vary seasonally, with greater increase in intermittent sites. These evidences contribute for the understanding of the spatio-temporal variation of the fish responses and fish resistance to perturbations by drought in tropical environments.

Keywords: Astyanax elachylepis, Antioxidant response, Brazilian savanna, Preparation for oxidative stress (POS), Seasonal variation.
Online version ISSN 1982-0224

Print version ISSN 1679-6225

Neotrop. Ichthyol.

vol. 18, no. 2, Maringá 2020
1 Universidade Estadual de Goiás, Câmpus Central, 75132-903 Anápolis, GO, Brazil. (LSO) luondei@yahoo.com.br (corresponding author); (FBT) fabricioteresa@yahoo.com.br.

2 Universidade Estadual Paulista “Júlio de Mesquita Filho”, Instituto de Biociências, Letras e Ciências Exatas, 15054-000 São José do Rio Preto, SP, Brazil. (DPG) daniellypgarcia@gmail.com; (AAF) andreia_a.felicio@hotmail.com; (DGHS) danilo-grunig.silva@unesp.br.

3 Fundação Universidade Regional de Blumenau, FURB, Departamento de Ciências Naturais, 89010-971 Blumenau, SC, Brazil. edualves1976@hotmail.com. 
A seca pode ser vista como uma perturbação em ambientes aquáticos lóticos e, em alguns casos, os peixes podem ser aprisionados em trechos lênticos (poços), onde a perda da qualidade da água pode causar estresse. Investigamos como esta condição extrema influencia biomarcadores bioquímicos de estresse oxidativo. Para isso, a resposta do caracídeo Astyanax elachylepis foi avaliada durante as estações seca e chuvosa em trechos intermitentes e perenes (controle) de riachos da savana brasileira (Cerrado). Predizemos que os biomarcadores seriam aumentados somente em peixes dos trechos intermitentes durante a estação seca, devido as condições restritivas dos poucos poços isolados que contém água. Como predito, os peixes do riacho intermitente apresentaram altos valores de MDA nas brânquias durante a estação seca, indicando maior estresse oxidativo. No fígado, os valores de MDA foram maiores na estação seca em ambos riachos, intermitente e perene, sugerindo uma resposta sazonal generalizada. Como esperado, algumas enzimas antioxidantes foram alteradas em peixes de trechos intermitentes durante a estação seca. Portanto, os biomarcadores de estresse oxidativo variam sazonalmente e essa variação é maior em trechos intermitentes. Essas evidências contribuem para a compreensão da variação espaço-temporal da resposta dos peixes e da sua resistência às perturbações por seca em ambientes tropicais.

Palavras-chave: Astyanax elachylepis, Preparação para o estresse oxidativo (POS), Resposta antioxidante, Savana brasileira, Variação sazonal.

\section{INTRODUCTION}

Drought can be viewd as a perturbation in running waters influencing water availability and biota responses (Lake, 2003). Decline in water availability often occur seasonally and it results in the decreasing or interrupting of the water flow (i.e. intermittent rivers) (Chapman, Kramer, 1991). Consequently, populations are confined to deeper pools where water may persist (Matthews, Marsh-Matthews, 2003; Silva, Teresa, 2017). In these situations, the reduction of space and the progressive degradation of the physicochemical water quality (e.g.reduction of dissolved oxygen, increase in temperature and concentrations of toxic nitrogen compounds) may seriously compromise the ability of aquatic organisms to maintain normal metabolism and may even jeopardize their survival (Matthews, Marsh-Matthews, 2003).

Among the responses triggered by natural and anthropogenic disturbances is oxidative stress, which is characterized by an imbalance in cellular redox metabolism. Under normal conditions, the cells have antioxidant defense systems, such as the antioxidant enzymes superoxide dismutase (SOD), catalase (CAT), glutathione peroxidase (GPx) and glutathione S-transferase (GST), which intercept oxidant species avoiding oxidative damage to macromolecules (Van der Oost et al., 2003). These biomarkers of oxidative stress are known to exhibit strong seasonal variation (Sheehan, Power, 1999; Aras et al., 2009; Hunt von Herbing et al., 2015), due to intrinsic (metabolic changes along ontogeny and reproductive cycles) and extrinsic (changes in environmental conditions) factors (Lau, Wong, 2003; Hermes-Lima et al., 2015). Changes in dissolved oxygen 
concentration, water temperature, water volume and food availability are examples of temporal environmental variations that potentially influence organismal responses to oxidative stress (Viarengo et al., 1991; Hunt von Herbing et al., 2015; Mustafa et al., 2015).

Previous field studies have attributed the seasonal variations in oxidative stress biomarkers mainly to temperature changes (Gorbi et al., 2005; Loro et al., 2015). However, most of these studies are carried out in temperate or subtropical regions, where seasonal variation in solar radiation promotes greater thermal variation throughout the seasons (Matthews, Marsh-Matthews, 2003). Conversely, in tropical environments, rainfall and water level coupled with their cascading effects on other limnological parameters such as dissolved oxygen, conductivity, and turbidity are the main sources of seasonal environmental changes (Allan, Castillo, 2007), creating specific environmental challenges whose biological consequences are poorly studied.

The seasonal oxidative stress response of organisms may also be variable spatially. For instance, organisms living in hydrologically more stable streams (i.e. perennial streams) could be less exposed to stressful conditions throughout seasons. Differently, organisms living in intermittent streams could be exposed to extreme environmental conditions (e.g. hypoxia) in periods of drought and could experience increased oxidative stress in comparison with rainy season or with organisms living in perennial and less harsh environments. Here, we tested this hypothesis by using the fish species Astyanax elachylepis Bertaco, Lucinda, 2005 (Teleostei, Characidae) as a model species in nearpristine streams of the Brazilian savanna (Cerrado). Astyanax elachylepis is an abundant water-column swimmer species in rivers and streams of the Tocantins-Araguaia ecoregion with a predominantly insectivorous diet (Bertaco, Lucinda, 2005; Silva, Teresa, 2017; Ávila et al., 2018). Astyanax species have been indicated as fish model in ecotoxicological studies due to its widespread occurrence in Neotropical waterbodies and sensitivity to water quality impairment (Barbieri et al., 2019; Tincani et al., 2019). We compared the response of this species during the dry and rainy seasons in an intermittent and a perennial stream. We predicted that the levels of lipid peroxidation (MDA) and antioxidant enzymes (CAT, G6PDH, GPx, GR and GST) would be higher in the dry season only in individuals from the intermittent sites due the harshness of the environment at this season (Chapman, Kramer, 1991). Considering that stress-induced responses are known to be tissue-specific (Kaur et al., 2005; Bocchetti et al., 2008), we evaluated biomarker responses in liver and gills. Particularly, the prediction was that biomarker responses in gills would be more pronounced due to direct exposure of this tissue to deteriored water conditions.

\section{MATERIAL AND METHODS}

Study area. We investigated the response of fish caught in Brazilian savanna (Cerrado) streams along a reach of 300 meters in two streams: $13^{\circ} 17^{\prime} 34^{\prime \prime}$; $48^{\circ} 38^{\prime} 32^{\prime \prime W}$ (intermittent), and $13^{\circ} 21^{\prime} 49^{\prime}$ 'S $48^{\circ} 35^{\prime} 57^{\prime \prime W}$ (perennial) located in Cental-West Brazil, Montividiu river drainage (Fig. 1), Araguaia-Tocantins ecoregion. Seasons are well marked in this region, with the dry season encompassing the period between April and September and the rainy season corresponding to the period between October and 
March (Ferreira, Tokarski, 2007). While some streams in this region have a relatively constant water flow throughout the year, others exhibit great oscillations in water level, with intermittency being common (Silva, Teresa, 2017). Both streams have riparian forest and are located in a conserved region of the basin, with around $80 \%$ of the remaining native vegetation (Borges et al., 2016; Barbosa et al., 2019). The predominant economic activity is extensive and low-productivity livestock that takes place in only 18.54\% of the basin (Borges et al., 2016). Previous studies carried out in the same region showed no signal of organic pollution in the streams (Barbosa et al., 2019).

Study design. We evaluated biomarkers from Astyanax elachylepis individuals captured in intermittent and perennial stream sites in the dry (September) and rainy (February) seasons. Six individuals (standard length $=8.3 \pm 0.5 \mathrm{~cm}$ ) were sampled in the intermittent stream, which experienced interruption in water flow during the dry period (intermittent-dry condition); 18 individuals (standard length $=11.6 \pm 1.6 \mathrm{~cm}$ ) in the same intermittent stream during the rainy season (intermittent-rainy condition); 11 individuals (standard length $=12.0 \pm 1.2 \mathrm{~cm}$ ) in the perennial river with uninterrupted water flow during the dry season (perennial-dry condition); 16 individuals (standard length $=11.2 \pm 1.0 \mathrm{~cm}$ ) in the same perennial stream during the rainy season (perennialrainy condition). Individuals in intermittent-dry condition were significantly smaller than individuals in intermittent-rainy and perennial conditions $(p<0.01$, two-wayANOVA, complemented by Tukey post-hoc test). Voucher individuals are deposited in the Coleção Zoológica da Universidade Estadual (UEG 889).

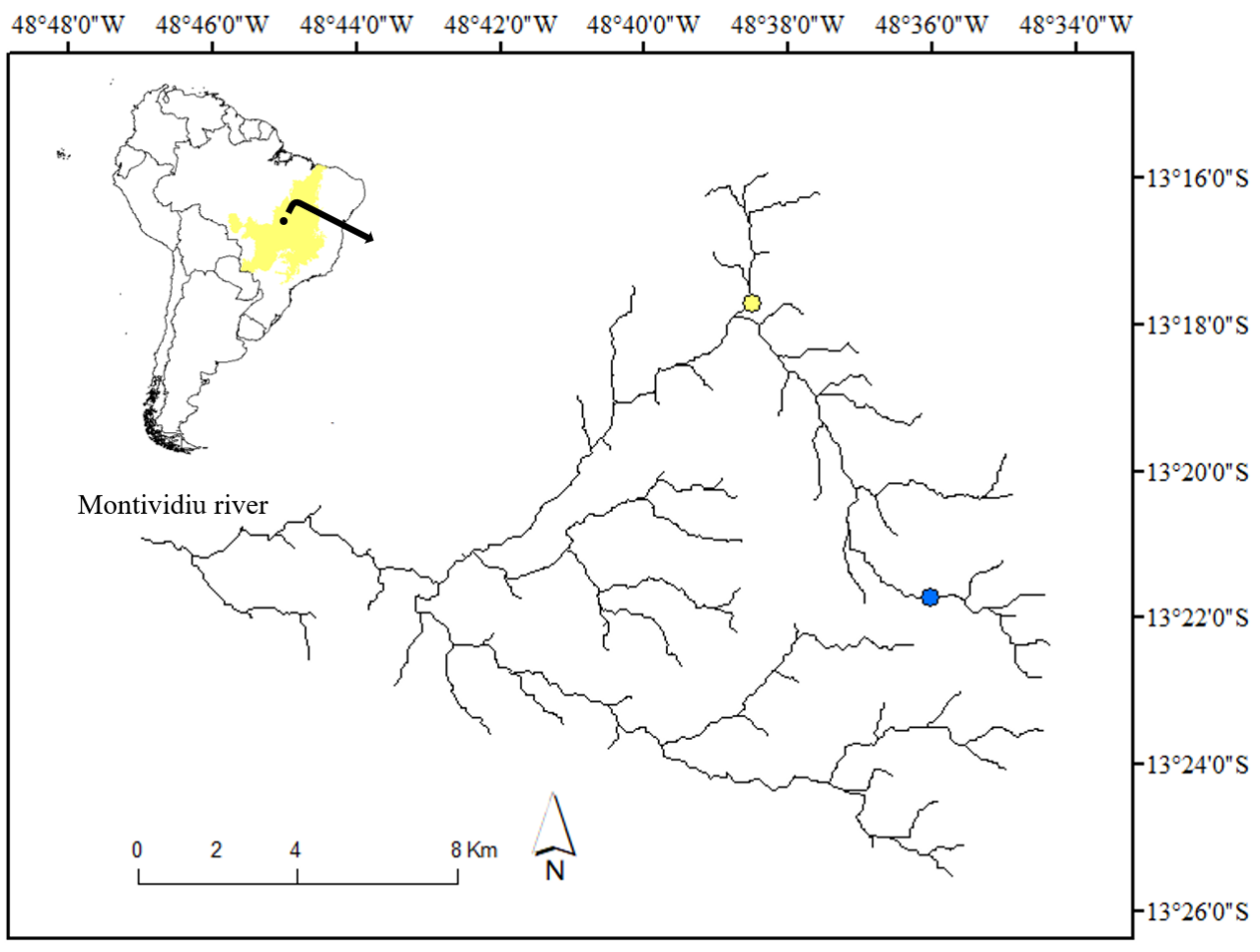

FIGURE 1 I Location of the Intermittent (yellow circle) and Perennial (blue circle) stream in the Montividiu drainage in the Brazilian Cerrado (yellow in the smaller map). 
Fish and environmental data. Environmental characteristics of the sampling sites were evaluated before fish sampling took place. The following limnological variables were measured using a multiparameter probe (YSI Professional Plus): dissolved oxygen, $\mathrm{pH}$, temperature and conductivity. Structural variables included wetted width (measured with a measuring tape) and depth (measured with a meter ruler).

Fish were captured by electrofishing with direct current adjusted to $2 \mathrm{~A}, 500 \mathrm{~V}, 35$ $\mathrm{Hz}$. This sampling technique is suitable for sampling fish in streams (Mazzoni et al., 2000). The liver and gills were extracted immediately after capture, frozen in liquid nitrogen in the field and stored at $-80^{\circ} \mathrm{C}$ in the laboratory until they were analyzed.

Lipid peroxidation. In order to assess lipid peroxidation levels, the product formed from the combination of malondialdehyde (MDA) and thiobarbituric acid (TBA) was detected by high performance liquid chromatography coupled with a UV/Vis detector. For this analysis, tissue samples were homogenized in $10 \mathrm{mM}$ Tris buffer, $\mathrm{pH} 8.0$ (1: 3 mass: volume). Then, $300 \mu \mathrm{l}$ of TBA diluted in $0.2 \mathrm{M} \mathrm{HCl}(0.4 \%$ solution) was added to the sample. The mixture was incubated at $90^{\circ} \mathrm{C}$ for $40 \mathrm{~min}$. Next $1 \mathrm{~mL}$ of n-butanol was added and samples were centrifuged at $2800 \mathrm{RCF}$ for $5 \mathrm{~min}$. The supernatant was collected and quantified by HPLC at $532 \mathrm{~nm}$, in terms of a malondialdehyde (MDA) standard calibration curve that had been previously prepared using the same procedure used for the samples (Almeida et al., 2003, 2004).

Enzymatic assays and protein quantification. The gill and liver samples were homogenized (1: 4 mass: volume) in $20 \mathrm{mM}$ Tris- $\mathrm{HCl} \mathrm{pH} 7.5$ buffer containing $0.5 \mathrm{M}$ sucrose, $1 \mathrm{mM}$ EDTA (Ethylenediaminetetraacetic acid), $1 \mathrm{mM}$ DTT (DLDithiothreitol), $0.15 \mathrm{M} \mathrm{KCl}$ and $1 \mathrm{mM}$ phenylmethylsulfonyl fluoride (PMSF) protease inhibitor. They were then centrifuged at $10000 \mathrm{RCF}$ for $20 \mathrm{~min}$ at $4^{\circ} \mathrm{C}$. The supernatant fraction was collected and centrifuged again at $50000 \mathrm{RCF}$ for $1 \mathrm{~h}$ at $4^{\circ} \mathrm{C}$. The supernatant fraction was separated into aliquots for the enzymatic analyses.

The enzymes CAT (Beutler, 1984), G6PDH (Beutler, 1994), GPx (Sies et al., 1979), GR (Beutler, 1969) and GST (Keen et al., 1976) were analyzed using spectrophotometer UV-Vis. The quantification of proteins, used to calculate the specific activity of each enzyme, was done using the Bradford method (Bradford, 1976).

Data analysis. In order to evaluate seasonal (dry $v$ s. rainy) and the stream (intermittent vs. perennial) effects, the values of MDA, CAT, G6PDH, GPx, GR, and GST obtained for gills and liver were compared using two-way ANOVA. A significant main effect of season would indicate temporal changes in the oxidative stress response, while a significant main effect of stream would indicate that the oxidative stress response varies spatially, between intermittent and perennial streams. Finally, an interaction effect would indicate that the effect of season is different between streams. Considering the hypothesis, the latter result is expected, with higher values of response variables (biomarkers) in the dry season, but only in the individuals from intermittent stream, which would be exposed to more stressful conditions. When an effect was significant in two-way ANOVA, we performed Tukey post-hot tests comparing levels of the respective factor.

In addition, the variation in the antioxidant response was evaluated using a multivariate approach. For this, enzyme activities were standardized (z-score) and the 
fish responses in the intermittent and perennial streams in the dry and rainy seasons were assessed using Similarity Analysis (ANOSIM). This analysis generates the R statistic that consists of comparing ranks of distances (Euclidian) between samples within and between conditions. $\mathrm{R}$ values close to 1 indicate greater similarity within the condition than between conditions. On the other hand, values of $\mathrm{R}$ close to zero indicate a smaller difference within the condition than between conditions, suggesting an absence of differences between conditions. To test the statistical significance, the observed $\mathrm{R}$ value is compared with values obtained from permutations of the distance matrix. NonMetric Multidimensional Scaling (NMDS) was used to visualize the ordering of the samples in two-dimensional space.

\section{RESULTS}

Overall, the limnological and structural variables were quite similar between streams during rainy seasons (Tab. 1). However, there was a clear difference in the concentration of dissolved oxygen between streams in the dry season, with a dramatically reduced concentration in the intermittent stream (Tab. 1).

As predicted fish from the intermittent-dry condition showed the highest MDA values in their gills than the those of other conditions (interaction effect, $F_{1,47}=16.7, p<$ 0.01 ) (Fig. 2). MDA liver values were higher in the dry season for both the intermittent and perennial streams (season effect, $F_{1,45}=175.7, p<0.01$ ) (Fig. 3).

In gills, the GPx activity was higher in the intermittent-dry condition (interaction effect, $F_{1,45}=193.9, p<0.01$ ) (Fig. 2), while GST activity was higher in the perennialdry condition (interaction effect, $F_{1,44}=44.8, p<0.01$ ) (Fig. 2). The activity of CAT, G6PDH and GR were greater in the dry season in both intermittent and perennial streams (season effect, $F_{1,45}=31.1$ for CAT, $F_{1,45}=30.7$ for G6PDH, $F_{1,45}=12.5$ for GR, $p<0.01$ ) (Fig. 2).

In relation to the liver, CAT activity were increased in the perennial-dry condition, while GR activity were higher in the intermittent-dry condition (interaction effect, $F_{1,43}=7.6$ for CAT, $F_{1,39}=17.8$ for GR, $p<0.01$ ) (Fig. 3). GPx activity was higher in the dry season in both, perennial and intermittent streams (season effect, $F_{1,33}=37.8$,

TABLE 1 I Values of the limnological and structural variables obtained in the intermittent and perennial streams during the dry and rainy seasons. The low dissolved oxygen in intermittent-dry condition is highlighted (bold).

\begin{tabular}{|r|c|c|c|c|}
\hline & \multicolumn{2}{|c|}{ Dry } & \multicolumn{2}{c|}{ Rainy } \\
\hline & Intermittent & Perennial & Intermittent & Perennial \\
\hline Dissolved oxygen (mg/L) & $\mathbf{1 . 5}$ & 8.0 & 6.6 & 6.8 \\
\hline $\mathrm{pH}$ & 6.6 & 7.5 & 7.1 & 7.5 \\
\hline Temperature $\left({ }^{\circ} \mathrm{C}\right)$ & 24.8 & 26.1 & 25.0 & 23.5 \\
\hline Conductivity $(\mu \mathrm{S})$ & 34.6 & 93.5 & 37.1 & 58.5 \\
\hline Width (m) & 1.2 & 4.7 & 3.1 & 4.8 \\
\hline Depth (cm) & 30 & 63.7 & 43.4 & 35.2 \\
\hline
\end{tabular}



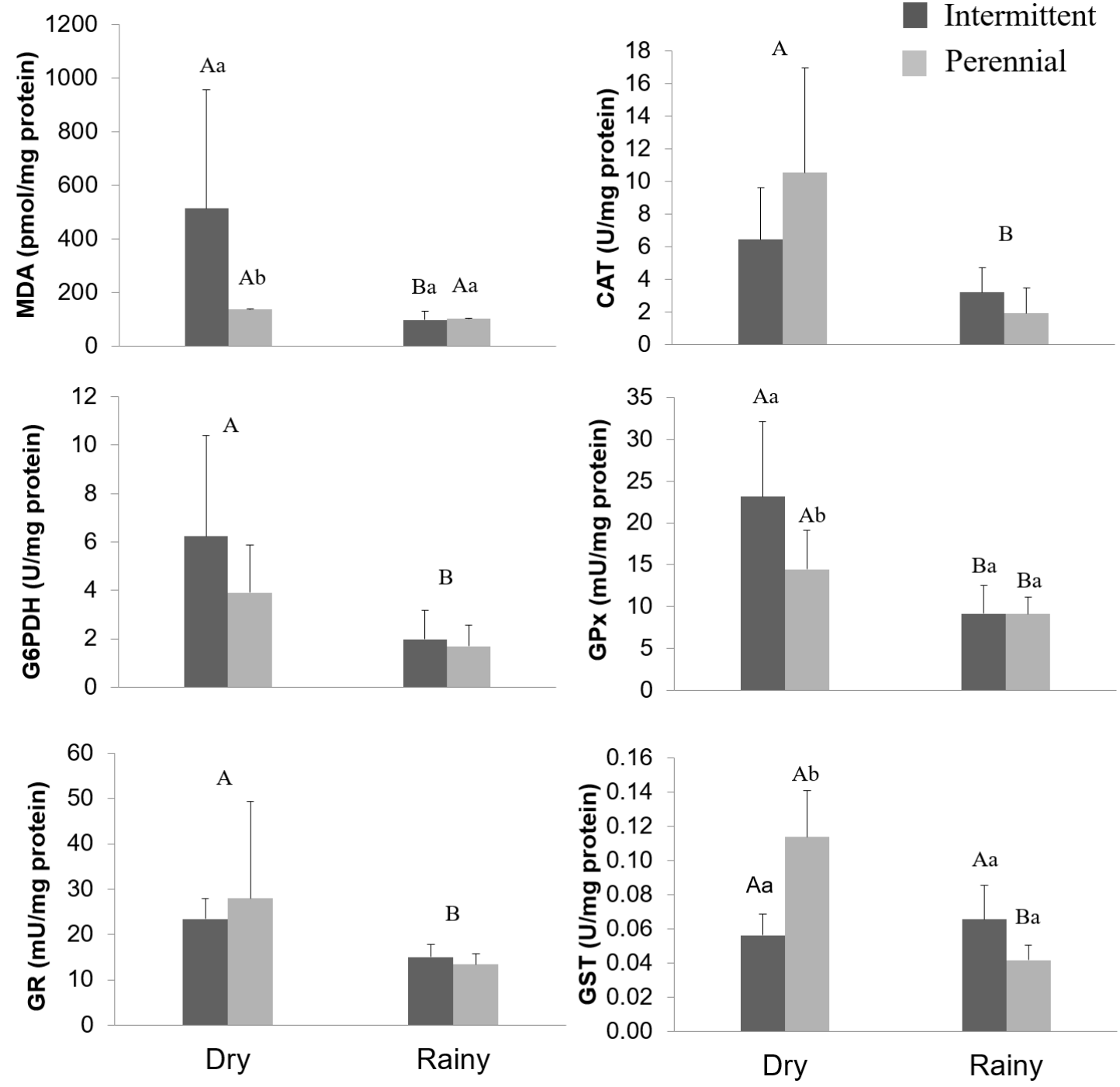

FIGURE 2 I MDA and enzymatic activity in the gills of Astyanax elachylepis from intermittent and perennial streams during dry and rainy seasons. Different capital letters indicate a significant difference (Tukey post-hoc test at $\mathrm{p}<0.05$ ) between seasons for a given stream, and different lower-case letters indicate a significant difference between intermittent and perennial streams within a given season. Differences are shown only between levels of the factors that had significant effect according to two-way ANOVA.

$p<0.01$ ) (Fig. 3). Conversely, G6PDH activity was lower in the dry period for both, perennial and intermittent streams (season effect, $F_{1,44}=17.5, p<0.01$ ) (Fig. 3). There were no seasonal or stream influences on GST ( $p>0.5)$ (Fig. 3).

From a multivariate perspective, the biomarkers significantly differed between the intermittent and perennial streams during the dry season (ANOSIM, $R=0.445, p<$ 0.01 ), but not in the rainy season (ANOSIM, $R=0.065, p=0.14$ ). Both streams had significant differences in biomarkers in relation to dry and rainy seasons (ANOSIM, intermittent stream: $R=0.736, p<0.01$, perennial stream: $R=0.72, p<0.01$ ) (Fig. 4). 

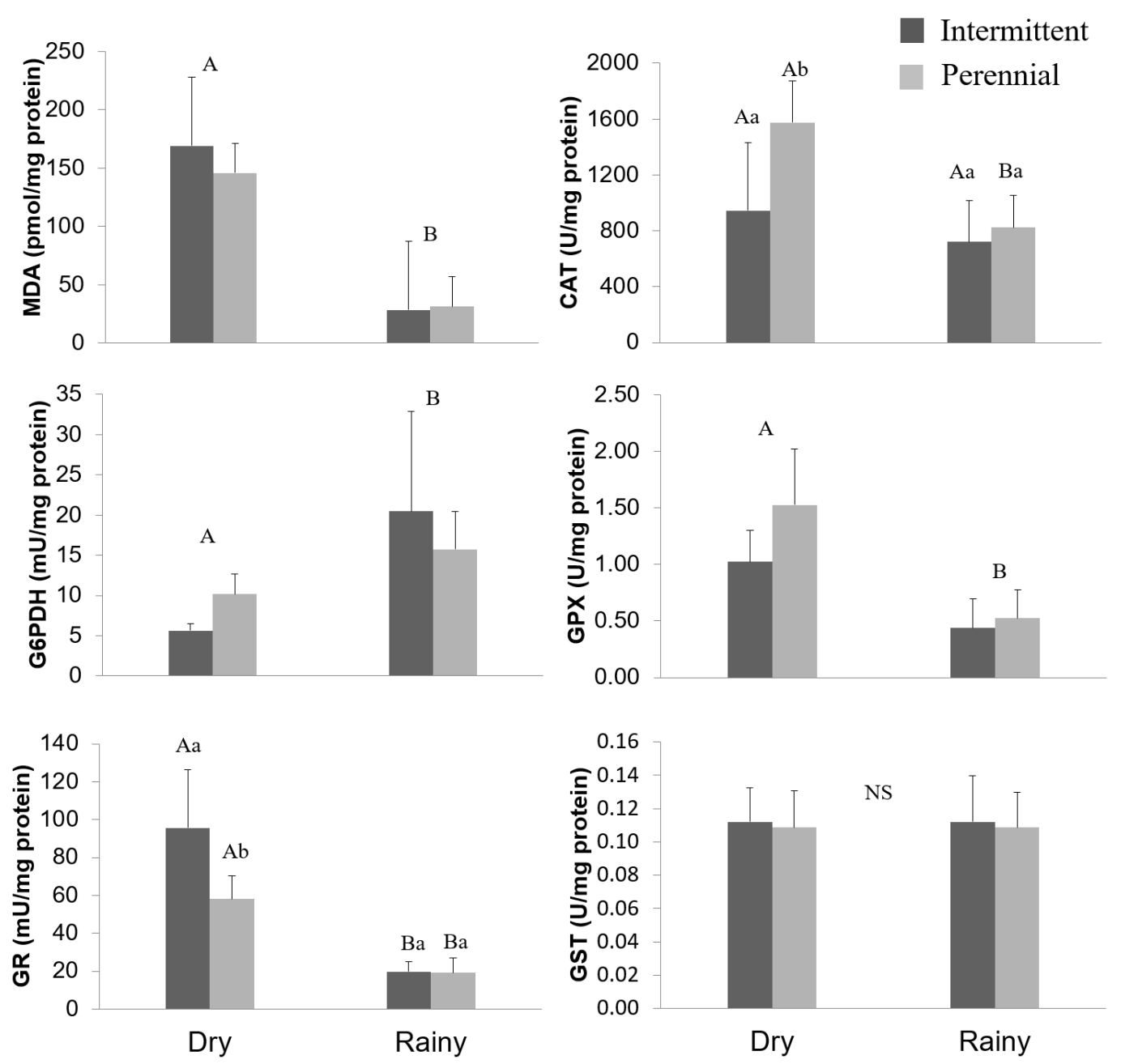

FIGURE 3 I MDA and enzymatic activity in the liver of Astyanax elachylepis from intermittent and perennial streams during dry and rainy seasons. Different capital letters indicate a significant difference (Tukey post-hoc test at $\mathrm{p}<0.05$ ) between seasons for a given stream, and different lower-case letters indicate a significant difference between intermittent and perennial streams within a given season. Differences are shown only between levels of the factors that had significant effect according to two-way ANOVA.

\section{DISCUSSION}

While most studies on oxidative stress reponses of fish are usually carried out under artificial conditions, this study presents evidences on how fish respond to natural environmental variations (spatial and temporal). The results indicate higher oxidative stress in fish during the dry season and show that this seasonal influence is potentialized if accompanied by alterations in the water flow regime. Under these conditions, animals are exposed to hypoxia, resulting in increased oxidative damage, as suggested by the higher levels of MDA. Furthermore, a seasonal effect regardless of interruption of water flow in some antioxidant enzymes was also identified. These biochemical responses should interact with other physiological and ecological adjustments influencing fish persistence in environments disturbed by drought (Magoulick, Kobza, 2003). 


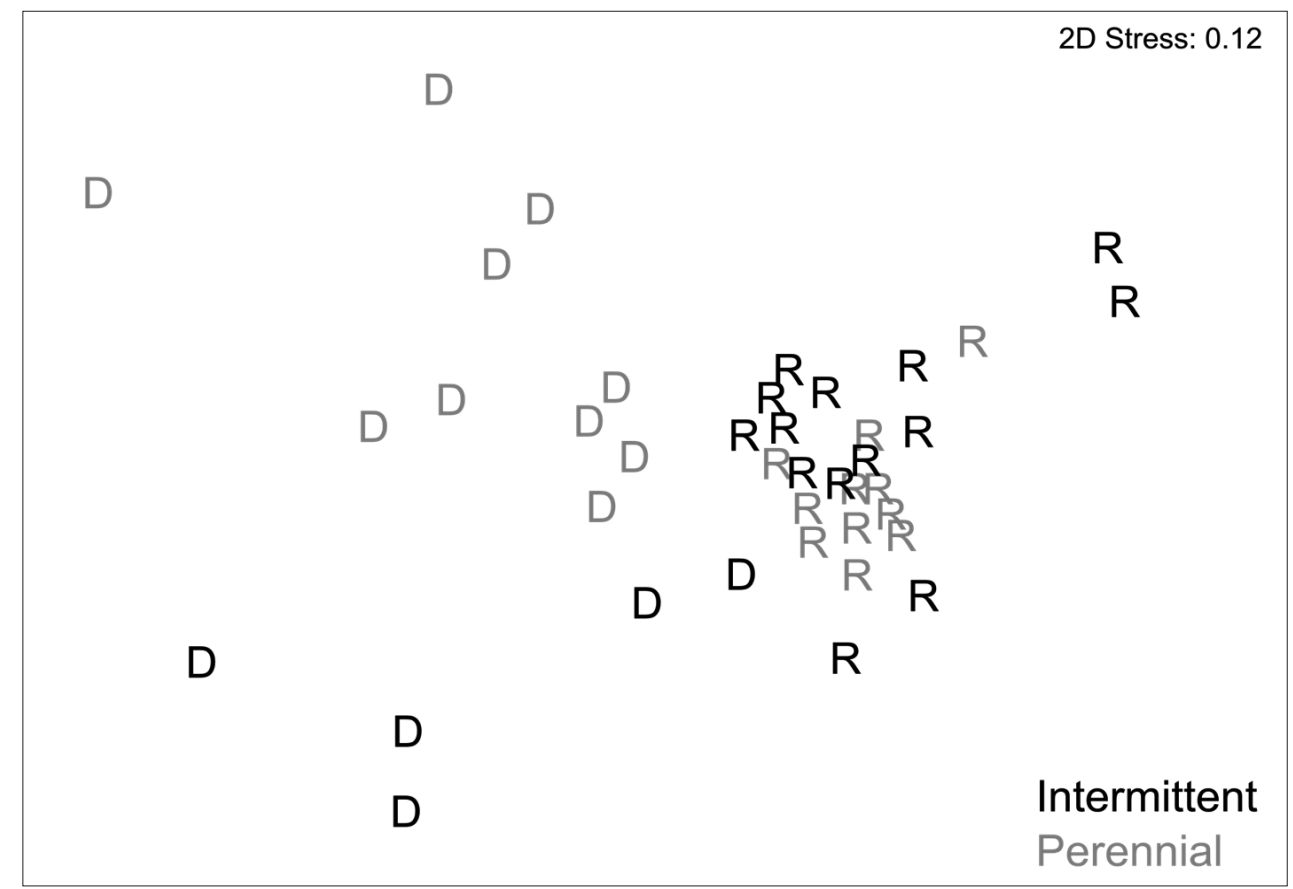

FIGURE 4 I Two-dimensional Non-Metric Multidimensional Scaling (NMDS) ordination showing biomarker responses of fish from intermittent and perennial streams in the dry (D) and rainy (R) seasons. The stress value of 0.12 indicates a good representation of the original data (Clarke, Warwick, 2001).

The hypothesis that the deterioration of water quality in extreme drought conditions causes oxidative stress was supported by our results, as shown by the increased lipid peroxidation in the gills of fish isolated in small pools of the intermittent stream during the dry season. Therefore, drought intensification and consequently the interruption of water flow of streams may be considered harmful to fish, as chronically increased oxidative stress is associated with the occurrence of diseases and pathophysiological conditions (Halliwell, Gutteridge, 2008). In turn, these changes may have repercussions at the population level and even affect the persistence of species in these streams. In fact, the difficulty in sampling fish in the intermittent stream during the dry season (only six specimens were captured even employing the same sampling effort) may reflect the deleterious conditions to which these organisms are exposed.

In the liver, the increase in lipid peroxidation occurred in the dry season in both streams, suggesting a generalized response to seasonal variation. Regarding the antioxidant response, our hypothesis was partially supported, since the response of some enzymes was exacerbated in the intermittent-dry condition. This was the case for GST and GPx in gill and catalase and GR in the liver. These results are consistent with the antioxidant response observed in fish exposed to hypoxia in other studies (Cooper et al., 2002; Lushchak et al., 2005). Because this study is correlational, we are unable to attribute the observed responses to any specific environmental factors. However, the oxygen concentration was markedly different between streams and reached levels below $2 \mathrm{mg} / \mathrm{L}$ in the intermittent stream, a severe and intolerable hypoxia condition 
for many aquatic organisms (Wu, 2002). Although the mechanisms by which hypoxia modulates oxidative stress are not fully understood, the evidence suggests that hypoxia promotes oxidative stress (i) via conversion of xanthine dehydrogenase to xanthine oxidase producing ROS and/or (ii) via inactivation of carriers from the transport chain of electrons, increasing the chance of electrons escaping and consequently reducing the number of oxygen molecules (Lushchak, Bagnyukova, 2007; Lushchak, 2011). Furthermore, the increase of antioxidant response has been reported in the literature as a preparative processes for oxidative damage expected to occur during reoxygenation (i.e. Preparation for Oxidative Stress theory) (Hermes-Lima, Storey, 1995; Hermes-Lima et al., 2015; Giraud-Billoud et al., 2019). Thus, it is plausible to assume that, at least in part, the responses observed in $A$. elachlepis individuals are mediated by changes in dissolved oxygen concentrations. Contrary to the expectations, we did not find a more pronounced antioxidant response in the gills than in the livers of $A$. elachlepis, indicating that both tissues are able to provide signals of fish responses to extreme environmental variations.

CAT in the liver and GST in the gills presented reduced activities in the intermittent stream in the dry season compared to the perennial stream. Decreased CAT activity might affect fish ability to deal with oxidative stress as it acts on one of the primary pathways of the antioxidant mechanism and has a potentiated effect on hepatocytes exposed to high levels of ROS (Jones et al., 1981). Under extremely stressful conditions, tissues may fail to trigger certain pathways of the antioxidant system (Wilhelm Filho et al., 2001). This may be the case for CAT and GST response in the fish of the intermittent stream, remaining these enzymes at low levels and contributing to the non-compensation of the elevated oxidative stress to which these fish were exposed.

The enzymes CAT, GR and G6PDH in the gills, and GPx and G6PDH in the liver, showed a seasonal effect, that is, they varied seasonally in both streams. This response may be attributed to seasonal changes in the metabolism of organisms directly or indirectly associated with extrinsic environmental factors independently of the interruption of water flow (e.g. food availability) (Chainy et al., 2016). Fishes of the Characidae family are knowm to have trophic plasticity, feeding on food items that fall on the surface of the water from the riparian forest, whose availability varies seasonally (Manna et al., 2012). The availability of resources tends to be lower in periods of drought, reducing diet breadth (Zaret, Rand, 1971; Winemiller, 1989). In fact, preliminary observations indicate that $A$. elachlepis has a diet composed almost exclusively of terrestrial insects during the dry season, but with a more diversified diet during the rainy season (Ávila et al., 2018). Thus, the lower availability of food items and a supposed worsening in the nutritional status of fish in the dry season could generate a stressful condition (Pascual et al., 2003; Furtado-Filho et al., 2007), capable of producing similar patterns of oxidative stress of fish in both streams. Unfortunately, we did not assess fish diet in this study, so that the speculated mechanism of seasonal control of antioxidant enzyme activities mediated by food resources availability demand further investigation.

The biomarkers showed no main effect of stream, indicating that the fish do not respond to the differences between streams independently of the seasons. These results indicate low spatial variability in biomarkers, a desirable property, since the use of 
biomarkers of oxidative stress in biomonitoring is usually based on the deviation of the reference sites that often have environmental conditions naturally different from the focal ones (Sanchez et al., 2013). When there is spatial variability in the responses due to conditions not related to anthropogenic impacts, the patterns obtained in the reference environment would not be comparable, which would reduce the predictive power of this type of approach (Sanchez et al., 2010). The differences between the streams only emerged in the dry season, when the environmental differences became evident, which is clearly observed in the ordination of the NMDS. The multivariate approach provided an integrated perspective of the results (Sanchez et al., 2007) coherent with the nature of antioxidant responses that do not occur independently, but instead are part of a complex system of synergistic responses.

In summary, the results show that the oxidative stress response is seasonally controlled and may be detected by biomarkers in the gills and liver. However, the response is potentiated in extreme conditions, such as in intermittent streams during drought, where fish are confined to small pools. Under these conditions, water quality is probably deteriorated and antioxidant defenses are unable to neutralize oxidative damages, especially in the gills, exposing fish to deleterious conditions. In a scenario in which drought become intensified due to climatic changes with possibility to shifts from perennial to intermittent flow regimes (Döll, Schmied, 2012), the capacity of fish persist in perturbed environments probably will dependend on their response to the oxidative challenges.

\section{ACKNOWLEDGMENTS}

We are grateful to Dianne M.A. Silva, Hugo O. Barbosa, João Vitor S. Ramos, Thais Correa and Rogério N. Oliveira for their assistance in the field; and to Priscila L. R. Dourado and Isabela G. Batalhão for assistance with laboratory activities; Marcelo Hermes-Lima for critical reading and suggestions that improved the manuscript. This study was funded by the Fundação de Amparo à Pesquisa do Estado de Goiás -FAPEG (201210267001078) and by CAPES / FAPEG AUXPE: 2036/2013. FBT and EAA receive grants from CNPq (306912/2018-0, 307603/2014-8, respectively).

\section{REFERENCES}

- Allan JD, Castillo MM. Stream Ecology: Structure and Function of Running Waters. Dordrecht: Springer; 2007.

- Almeida EA, Marques SA, Klitzke CF, Bainy ACD, de Medeiros MHG, Di Mascio P, Loureiro APM. DNA damage in digestive gland and mantle tissue of the mussel Perna perna. Comp Biochem Physiol C Toxicol Pharmacol. 2003; 135(3):295-303. https://doi.org/10.1016/ S1532-0456(03)00117-0
- Almeida EA, Miyamoto S, Bainy ACD, de Medeiros MHG, Di Mascio P. Protective effect of phospholipid hydroperoxide glutathione peroxidase (PHGPX) against lipid peroxidation in mussels Perna perna exposed to different metals. Mar Pollut Bull. 2004; 49(5-6):386-92. https://doi.org/10.1016/j. marpolbul.2004.02.020 
- Aras NM, Bayir A, Sirkecioglu AN, Bayir M, Aksakal E, Haliloglu I. Seasonal changes in antioxidant defence system of liver and gills of Salmo trutta caspius, Salmo trutta labrax and Salmo trutta macrostigma. J Fish Biol. 2009; 74(4):842-56. https://doi. org/10.1111/j.1095-8649.2008.02164.x

- Ávila MP, Carvalho RN, Casatti L, Simião-Ferreira J, Morais LF, Teresa FB. Metrics derived from fish assemblages as indicators of environmental degradation in Cerrado streams. Zoologia. 2018; 35:1-8. https://doi.org/10.3897/zoologia.35.e12895

- Barbieri B, Ferrarini AMT, Rezende KFO, Martinez DST, Alves OL. Effects of multiwalled carbon nanotubes and carbofuran on metabolism in Astyanax ribeirae, a native species. Fish Physiol. Biochem. 2019; 45(1):417-26. https://doi. org/10.1007/s10695-018-0573-2

- Barbosa HO, Borges PP, Dala-Corte RB, Martins PTA, Teresa FB. Relative importance of local and landscape variables on fish assemblages in streams of Brazilian savanna. Fish Manag Ecol. 2019; 26(2):11930. https://doi.org/10.1111/fme.12331

- Bertaco VA, Lucinda PHF. Astyanax elachylepis, a new characid fish from the rio Tocantins drainage, Brazil (Teleostei: Characidae). Neotrop Ichthyol. 2005; 3(3):389-94. https://doi.org/10.1590/S167962252005000300006

- Beutler E. Effect of flavin compounds on glutathione reductase activity: in vivo and in vitro studies. J Clin Invest. 1969; 48(10):195766. https://doi.org/10.1172/JCI106162

- Beutler E. Red cell metabolism: a manual of biochemical methods. London: Grune \& Stratton; 1984.

- Beutler E. G6PD deficiency. Blood. 1994; 84(11):3613-36.

- Borges PP, Martins PTA, Ferreira AA. Uso e ocupação do solo por meio de uma série histórica na bacia do rio Santa Teresa em Goiás. RBGF. 2016; 9(1):296-304. https:// doi.org/10.26848/rbgf.v9.1.p296-304

- Bocchetti R, Lamberti CV, Pisanelli B, Razzetti EM, Maggi C, Catalano B, Sesta G, Martuccio G, Gabellini M, Regoli F. Seasonal variations of exposure biomarkers, oxidative stress responses and cell damage in the clams, Tapes philippinarum, and mussels, Mytilus galloprovincialis, from Adriatic sea. Mar Environ Res. 2008; 66(1):24-26. https://doi. org/10.1016/j.marenvres.2008.02.013
- Bradford MM. A rapid and sensitive method for the quantitation of microgram quantities of protein utilizing the principle of protein-dye binding. Anal Biochem. 1976; 72(1-2):248-54. https://doi. org/10.1016/0003-2697(76)90527-3

- Chainy GBN, Paital B, Dandapat J. An overview of seasonal changes in oxidative stress and antioxidant defence parameters in some invertebrate and vertebrate species. Scientifica (Cairo). 2016; 2016:6126570. https://doi. org/10.1155/2016/6126570

- Chapman LJ, Kramer DL. Limnological observations of an intermittent tropical dry forest stream. Hydrobiologia. 1991; 226(3):153-66. https://doi.org/10.1007/ BF00006857

- Clarke KR, Warwick RM. Change in marine communities: an approach to statistical analysis and interpretation. Plymouth: Plymouth Marine Laboratory; 2001.

- Cooper RU, Clough LM, Farwell MA, West TL. Hypoxia-induced metabolic and antioxidant enzymatic activities in the estuarine fish Leiostomus xanthurus. J Exp Mar Biol Ecol. 2002; 279(1-2):120. https://doi.org/10.1016/S00220981(02)00329-5

- Döll P, Schmied HM. How is the impact of climate change on river flow regimes related to the impact on mean annual runoff? A global-scale analysis. Environ Res Lett. 2012; 7:1-11. https://doi. org/10.1088/1748-9326/7/1/014037

- Ferreira EABF, Tokarski DJ. Bacia Hidrográfica do Alto Tocantins, Retrato e Reflexões. Brasil: ECODATA WWF-Brasil; 2007.

- Furtado-Filho OV, Polcheira C, Machado DP, Mourão G, Hermes-Lima M. Selected oxidative stress markers in a South American crocodilian species. Comp Biochem Physiol C. 2007; 146(12):241-54. https://doi.org/10.1016/j. cbpc.2006.11.017 
- Giraud-Billoud M, Rivera-Ingraham GA, Moreira DC, Burmester T, CastroVazquez A, Carvajalino-Fernández JM, Dafre A, Niu C, Tremblay N, Paital B, Rosa R, Storey JM, Vega IA, Zhang W, Yepiz-Plascencia G, Zenteno-Savin T, Storey KB, Hermes-Lima M. Twenty years of the 'Preparation for Oxidative Stress' (POS) theory: Ecophysiological advantages and molecular strategies. Comp Biochem Physiol A Mol Integr Physiol. 2019; 234:36-49. https://doi.org/10.1016/j. cbpa.2019.04.004

- Gorbi SC, Baldini C, Regoli F. Seasonal variability of metallothioneins, cytochrome P450, bile metabolites and oxyradical metabolism in the European eel Anguilla anguilla L. (Anguillidae) and striped mullet Mugil cephalus L. (Mugilidae). Arch Environ Contam Toxicol. 2005; 49(1):62-70. https://doi. org/10.1007/s00244-004-0150-9

- Halliwell BC, Gutteridge JM. Free Radicals in Biology and Medicine. New York: Oxford University Press; 2008.

- Hermes-Lima M, Moreira DC, RiveraIngraham GA, Giraud-Billoud M, Genaro-Mattos TC, Campos EG. Preparation for oxidative stress under hypoxia and metabolic depression: Revisiting the proposal two decades later. Free Radical Biol Med. 2015; 89:1122-43. https://doi.org/10.1016/j. freeradbiomed.2015.07.156

- Hermes-Lima M, Storey KB. Antioxidant defenses and metabolic depression in a pulmonate land snail. Am J Physiol. 1995; 268(6):R1386-R1393. https://doi. org/10.1152/ajpregu.1995.268.6.R1386

- Hunt von Herbing I, Pan TCF, MéndezSánchez F, Garduño-Paz M, HernándezGallegos O, Ruiz-Gómez ML, RodríguezVargas G. Chronic stress of rainbow trout Oncorhynchus mykiss at high altitude: a field study. J Fish Biol. 2015; 87(1):138-58. https://doi.org/10.1111/jfb.12710

- Jones DP, Eklöw L, Thor H, Orrenius S. Metabolism of hydrogen peroxide in isolated hepatocytes: relative contributions of catalase and glutathione peroxidase in decomposition of endogenously generated $\mathrm{H}_{2} \mathrm{O}_{2}$. Arch Biochem Biophys. 1981; 210(2):50516. https://doi.org/10.1016/00039861(81)90215-0
- Kaur M, Atif F, Ali M, Rehman H, Raisuddin S. Heat stress-induced alterations of antioxidants in the freshwater fish Channa punctata Bloch. J Fish Biol. 2005; 67(6):1653-65. https://doi. org/10.1111/j.1095-8649.2005.00872.x

- Keen JH, Habig WH, Jakoby WB. Mechanism for the several activities of the glutathione S-transferases. J Biol Chem. 1976; 251(20):6183-88.

- Lake PS. Ecological effects of perturbation by drought in flowing waters. Freshw Biol. 2003; 48(7):1161-72. https://doi.org/10.1046/ j.1365-2427.2003.01086.x

- Lau PS, Wong HL. Effect of size, tissue parts and location on six biochemical markers in the green-lipped mussel, Perna viridis. Mar Pollut Bull. 2003; 46(12):1563-72. https://doi.org/10.1016/ S0025-326X(03)00321-7

- Loro VL, Murussi C, Menezes C, Leitemperger J, Severo E, Guerra L, Costa M, Perazzo GX, Zanella R. Spatial and temporal biomarkers responses of Astyanax jacuhiensis (Cope, 1894) (Characiformes: Characidae) from the middle rio Uruguai, Brazil. Neotrop Ichthyol. 2015; 13(3):569-78. https://doi. org/10.1590/1982-0224-20140146

- Lushchak VI. Environmentally induced oxidative stress in aquatic animals. Aquat Toxicol. 2011; 101(1):13-30. https://doi. org/10.1016/j.aquatox.2010.10.006

- Lushchak VI, Bagnyukova TV. Hypoxia induces oxidative stress in tissues of a goby, the rotan Perccottus glenii. Comp Biochem Physiol B Biochem Mol Biol. 2007; 148(4):390-97. https://doi.org/10.1016/j. cbpb.2007.07.007

- Lushchak VI, Bagnyukova TV, Lushchak OV, Storey JM, Storey KB. Hypoxia and recovery perturb free radical processes and antioxidant potential in common carp (Cyprinus carpio) tissues. Int J Biochem Cell Biol. 2005; 37(6):1319-30. https://doi. org/10.1016/j.biocel.2005.01.006

- Magoulick DD, Kobza RM. The role of refugia for fishes during drought: a review and synthesis. Freshw Biol. 2003; 48(7):1186-98. https://doi.org/10.1046/ j.1365-2427.2003.01089.x

- Manna LR, Rezende CF, Mazzoni R. Plasticity in the diet of Astyanax taeniatus in a coastal stream from south-east Brazil. Braz J Biol. 2012; 72(4):919-28. https://doi. org/10.1590/S1519-69842012000500020 
- Matthews WJ, Marsh-Matthews E. Effects of drought on fish across axes of space, time and ecological complexity. Freshw Biol. 2003; 48(7):1232-53. https://doi. org/10.1046/j.1365-2427.2003.01087.x

- Mazzoni R, Fenerich-Verani N, Caramaschi EP. Electrofishing as a sampling technique for coastal stream fish populations and communities in the southeast of Brazil. Rev Bras Biol. 2000; 60(2):205-16. https://doi.org/10.1590/S003471082000000200003

- Mustafa SA, Karieb SS, Davies SJ, Jha AN. Assessment of oxidative damage to DNA, transcriptional expression of key genes, lipid peroxidation and histopathological changes in carp Cyprinus carpio L. following exposure to chronic hypoxic and subsequent recovery in normoxic conditions. Mutagenesis. 2015; 30(1):10716. https://doi.org/10.1093/mutage/geu048

- Pascual P, Pedrajas JR, Toribio F, López-Barea J, Peinado J. Effect of food deprivation on oxidative stress biomarkers in fish (Sparus aurata). Chem Biol Interact. 2003; 145(2):191-99. https://doi.org/10.1016/ S0009-2797(03)00002-4

- Sanchez W, Aït-Aïssa S, Palluel O, Ditche JM, Porcher JM. Preliminary investigation of multi-biomarker responses in threespined stickleback (Gasterosteus aculeatus L.) sampled in contaminated streams. Ecotoxicology. 2007; 16(2):279-87. https:// doi.org/10.1007/s10646-006-0131-z

- Sanchez W, Piccini B, Maillot-Marechal E, Porcher JM. Comparison of two reference systems for biomarker data analysis in a freshwater biomonitoring context. Environ Int. 2010; 36(4):377-82. https://doi.org/10.1016/j.envint.2010.02.006

- Sanchez W, Burgeot T, Porcher JM. A novel "Integrated Biomarker Response" calculation based on reference deviation concept. Environ Sci Pollut Res Int. 2013. 20(5):2721-25. https://doi.org/10.1007/ s11356-012-1359-1

- Sheehan D, Power A. Effects of seasonality on xenobiotic and antioxidant defence mechanisms of bivalve molluscs. Comp Biochem Physiol C Pharmacol Toxicol Endocrinol. 1999; 123(3):193-99. https:// doi.org/10.1016/S0742-8413(99)00033-X

- Sies H, Koch OR, Martino E, Boveris A. Increased biliary glutathione disulfide release in chronically ethanol-treated rats. FEBS Lett. 1979; 103(2):287-90. https://doi. org/10.1016/0014-5793(79)81346-0
- Silva DMA, Teresa FB. Response of fish communities to intense drought in Brazilian savanna streams. Rev Ambient Água. 2017; 12(4):618-28. https://doi. org/10.4136/ambi-agua.2093

- Tincani FH, Santos GS, Azevedo ACB, Marques AEML, Pereira LS, Castellano GC, da Silva TA, Galvana GL, Chimentão FG, Silva CP, Oliveira Ribeiro CA, Silva de Assis HC, Campos SX, Ramsdorf WA, Cestari MM. Climbing the taxonomic ladder: Could a genus be used as bioindicator? The ecotoxicological relationship between biomarkers of Astyanax altiparanae, Astyanax bifasciatus and Astyanax ribeirae. Ecol. Indic. 2019. 106:1054742. https://doi.org/10.1016/j. ecolind.2019.105474

- Van der Oost R, Beyer J, Vermeulen NPE. Fish bioaccumulation and biomarkers in environmental risk assessment: a review. Environ Toxicol Pharmacol. 2003; 13(2):57-149. https://doi.org/10.1016/S13826689(02)00126-6

- Viarengo A, Canesi L, Pertica M, Livingstone DR. Seasonal variations in the antioxidant defence systems and lipid peroxidation of the digestive gland of mussels. Comp Biochem Physiol C Comp Pharmacol. 1991; 100(1-2):187-90. https:// doi.org/10.1016/0742-8413(91)90151-I

- Wilhelm Filho D, Torres MA, Tribess TB, Pedrosa RC, Soares CH. Influence of season and pollution on the antioxidant defenses of the cichlid fish acará (Geophagus brasiliensis). Braz J Med Biol Res. 2001; 34(6):719-26. https://doi. org/10.1590/S0100-879X2001000600004

- Winemiller KO. Ontogenetic diet shifts and resource partitioning among piscivorous fishes in the Venezuelan llanos. Environ Biol Fishes. 1989; 26(3):177-99. https://doi.org/10.1007/ BF00004815

- Wu RSS. Hypoxia: from molecular responses to ecosystem responses. Mar Pollut Bull. 2002; 45(1-12):35-45. https:// doi.org/10.1016/S0025-326X(02)00061-9

- Zaret TM, Rand AS. Competition in tropical stream fishes: support for the competitive exclusion principle. Ecology. 1971; 52(2):336-42. https://doi. org/10.2307/1934593 


\section{Neotropical |chthyology}

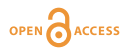

\section{(c) (i)}

This is an open access article under the terms of the Creative Commons Attribution License, which permits use, distribution and reproduction in any medium,
provided the original work is properly cited.

Distributed under

Creative Commons CC-BY 4.0

() 2020 The Authors.

Diversity and Distributions Published by SBI

\section{AUTHOR'S CONTRIBUTION @}

Luciana de Souza Ondei: Conceptualization, Data curation, Funding acquisition, Methodology, Project administration, Resources, Writing-original draft, Writing-review \& editing.

Fabricio Barreto Teresa: Conceptualization, Data curation, Methodology, Formal analysis, Writingoriginal draft, Writing-review \& editing.

Danielly Pereira Garcia: Methodology, Writing-original draft.

Andréia Arantes Felício: Methodology, Writing-original draft.

Danilo Grünig Humberto Silva: Methodology, Writing-original draft.

Eduardo Alves Almeida: Conceptualization, Funding acquisition, Methodology, Resources, Supervision, Writing-original draft.

\section{ETHICAL STATEMENT}

Fish collection was authorized by the Instituto Chico Mendes de Conservação da Biodiversidade (license no. 34144-1) and the project was approved by the Ethics Committee on Animal Use / CEUA of the Universidade Estadual de Goiás (protocol number 006/2015).

\section{COMPETING INTERESTS}

The authors declare no competing interests.

\section{HOW TO CITE THIS ARTICLE}

- Ondei LS, Teresa FB, Garcia DP, Felício AA, da Silva DGH, de Almeida EA. Fish biomarkers responses to perturbation by drought in streams. Neotrop Ichthyol. 2020; 18(2):e190130. https://doi.org/10.1590/1982-0224-2019-0130 